\title{
MODERATE PHYSICAL ACTIVITY IMPROVES INFLAMMATORY MARKERS (IL-6 AND TNF ALPHA) AND DIABETIC PROFILE IN THE PREDIABETIC POPULATION
}

\author{
Zubia SHAH ${ }^{1}$, Abdul Waheed MUGHAL ${ }^{2}$, Sherbaz KHAN ${ }^{1}$, \\ Saman TAUQIR ${ }^{3}$, Inayat $\mathrm{SHAH}^{1}$ \\ ${ }^{1}$ Institute of Basic Medical Science, Khyber Medical University, Peshawar, Pakistan \\ ${ }^{2}$ Department of Sports Science and Physical Education, Sarhad University of Science and \\ Information Technology, Pakistan \\ ${ }^{3}$ Department of Physiology, Gandhara University, Peshawar, Pakistan \\ Corresponding author: \\ Inayat $\mathrm{SHAH}, \mathrm{PhD}$ \\ Associate Professor (Director) \\ Institute of Basic Medical Sciences, Khyber Medical University Peshawar, Khyber \\ Pakhtunkhwa Pakistan 25000 \\ Phone: +923321431414 \\ E-mail: drinayatshah@kmu.edu.pk
}

\begin{abstract}
Purpose: Prediabetes is a health condition that precedes type II diabetes. Globally, prevalence of prediabetes is on the rise and approximately 37\% of Pakistani populations are suffering from it. Apart from many other factors, inflammatory markers, especially Interleukin - 6 (IL-6), and Tumor Necrosis Factor - Alpha (TNF- $\alpha)$ play a significant part in the development of prediabetes to diabetes. How exercise affects the inflammatory cytokines is elucidated but not completely understood.

Methods: A non-commercial experimental trial including a total of 48 participants (36 males and 12 females) aged $30.7 \pm 7.80$ years (mean $\pm S D$ ) was carried out after ethical approval and written informed consent. Demographic data, body plethysmography, exercise parameters, diabetic and inflammatory markers were determined at pre- and post-interventional stages. The exact intensity of exercise capable of eliciting the required heart rate was determined and each participant was asked to perform moderate intensity exercise (45 minutes including warm up and cool down) at home, monitored through pedometers, 5 days a week for 12 weeks.

Results: Twelve weeks of moderate intensity aerobic exercise (at 55\% to 65\% of Predicted Maximum Heart Rate [PMHR]) had significant positive effects on body composition, including body mass index (BMI) $(<0.001)$, body mass $(<0.001)$, diabetic parameters (Fasting Blood Sugar [FBS] (0.02), glycated hemoglobin HbA1c [0.001])
\end{abstract}


and inflammatory parameters (IL-6 [0.018] and TNF- $\alpha$ [0.02]). The effects were almost identical for males and females (mild differences).

Conclusion: Moderate intensity exercise significantly decreases the levels of circulating inflammatory cytokines and improves the diabetic profile in prediabetics. In addition, such exercise is easy to incorporate into the lifestyle of the prediabetic population and can be used as an effective strategy for preventing the development of diabetes.

Keywords: prediabetes, IL-6, TNF- $\alpha$, inflammatory cytokine, moderate intensity aerobic exercise

\section{ZMERNA TELESNA AKTIVNOST IZBOLJŠA VREDNOSTI VNETNIH KAZALCEV (IL-6 IN TNF-ALFA) IN DIABETIČNIH PARAMETROV PRI PREDDIABETIČNI POPULACIJI}

\section{IZVLE ¿̌EK}

Cilj: Preddiabetes je zdravstveno stanje, predstopnja sladkorne bolezni tipa 2. Njegova razširjenost $v$ svetovnem merilu narašča, omenjeno stanje pa je prisotno že pri $37 \%$ pakistanskega prebivalstva. Poleg številnih drugih dejavnikov imajo pri napredovanju preddiabetesa $v$ diabetes pomembno vlogo vnetni kazalci, predvsem IL-6 in TNF- $\alpha$. Prispevek osvetljuje vpliv telesne aktivnosti na vnetne citokine, ki pa ga v celoti zaenkrat še ne znamo pojasniti.

Metode: Po pridobitvi etične odobritve in pisnih soglasij smo izvedli nekomercialen poskus z 48 udeleženci (36 moškimi in 12 ženskami) v povprečni starosti 30,7 7 7,80 let. Demografske podatke, telesno pletizmografijo, parametre telesne aktivnosti ter diabetične in vnetne kazalce smo določali pred začetkom in ob koncu poskusa. Natančno smo opredelili stopnjo intenzivnosti vadbe, potrebno za dosego zahtevanega srčnega utripa, in vse udeležence prosili, naj 12 tednov po petkrat tedensko izvajajo zmerno intenzivno telesno vadbo (45 minut, vključno z ogrevanjem in ohlajanjem).

Rezultati: Dvanajsttedensko izvajanje zmerno intenzivne aerobne vadbe (pri $55 \%$ do $65 \%$ predvidenega MSU) je zelo pozitivno učinkovalo na telesno zgradbo, med drugim na ITM $(<0,001)$, težo $(<0,001)$, diabetične parametre $(F B S(0,02), H b A 1 c$ $(0,001))$ ter vnetne parametre $(I L-6(0,018)$ in $T N F-\alpha(0,02))$. Učinki so bili z le rahlimi razlikami praktično enaki pri moških in ženskah.

Zaključek: Zmerno intenzivna telesna aktivnost znatno zniža raven vnetnih citokinov v krvnem obtoku. Zmerno intenzivne aerobne vadbe ni težko vključiti v življenjski slog preddiabetične populacije in jo je zato moč uporabiti kot eno od učinkovitejših strategij za preprečevanje razvoja sladkorne bolezni.

Ključne besede: preddiabetes, IL-6, TNF- $\alpha$, vnetni citokin, zmerno intenzivna aerobna vadba 


\section{INTRODUCTION}

Diabetes is a metabolic disorder of epidemic nature worldwide, with defective insulin secretion, action, or combination of both that results in high blood sugar with ultimate damage to different systems of the body including visual, urinary, nervous, and cardiac systems. Diabetes is usually preceded by prediabetes, which is a stage of subclinical hyperglycaemia, and at this stage the risk of developing type II diabetes mellitus (T2DM) is very high. A recent survey has estimated that there are about 38 million prediabetic people in Pakistan (Aamir et al., 2019). It is highly recommended that, due to increased prevalence of co-morbid conditions in patients with type II diabetes mellitus, proper exercise programs should be devised based on the best possible research evidence and expertise (Hordern et al., 2012).

The pathology of diabetes is multi-factorial, complex, and involves the imbalance of many inflammatory cytokines, including IL- 6 and TNF- $\alpha$. IL- 6 is mainly released by muscles during exercise and acts as both a pro- and anti-inflammatory marker (Golbidi, Badran \& Laher, 2011). Mode and type of exercise affects the IL-6 plasma levels differently, as predominantly more muscle mass involvement in any exercise enhances IL-6 more efficiently. Insulin resistance in prediabetes and diabetes is mostly TNF- $\alpha$ induced and exercise plays a role in inhibiting this resistance (Golbidi et al., 2011).

TNF- $\alpha$ is a cytokine with a vital role in fatty acid metabolism and glucose regulation. Its levels are high in obese and diabetic patients (Straczkowski et al., 2001). Regular exercise decreases the activity of TNF- $\alpha$ system activity and results in increased insulin sensitivity (Straczkowski et al., 2001). But limited information is available in this regard. Exercise has been reported to significantly reduce the endothelial dysfunction and levels of inflammatory marks, which are the two hallmark factors in the development of type II diabetes mellitus (Hopps, Canino, \& Caimi, 2011).

Regular exercise has been proven to be helpful in modifying many aspects during prediabetic and diabetic conditions, ranging from metabolism of glucose to respiratory capacity of the muscles and cellular respiration at mitochondria along with improving $\beta$-oxidation (Earnest, 2008). According to exercise guidelines, aerobic exercise ranging from $40 \%$ to $85 \%$ maximal oxygen consumption (VO2 max) can be performed easily in sedentary populations (Earnest, 2008). The existing evidence shows that development of diabetes mellitus (DM) occurs more frequently in inactive individuals; exercise training along with modification in lifestyle is reported to delay the onset of full-blown diabetes, and improve impaired glucose tolerance (IGT) and impaired fasting glucose (IFG) at a prediabetic stage (Malin, Gerber, Chipkin, \& Braun, 2012).

As discussed earlier, a large percentage of Pakistani population is suffering from prediabetes, which suggests the possibility of a massive disease burden in the near future. Therefore, it is timely to investigate the baseline levels of inflammatory markers in prediabetics and how 3 months of regular moderate intensity exercise affects them. 


\section{METHODS}

A total of 48 young prediabetic patients aged $30.7 \pm 7.80$ years were recruited using convenience sampling technique. The non-commercial experimental trial included 36 males $(75 \%)$ and 12 females $(25 \%)$ who were recruited into 12 -weeks moderate intensity exercise protocol at 55\% to $65 \%$ PMHR at the exercise lab of Khyber Medical University, Peshawar, after ethical approval granted by the Ethical Review Board of Khyber Medical University (DIR/KMU-AS\&RB/TC/001167). Using G Power 3.1.9.2 software by taking IL-6 values for control $(2.43 \pm 0.32)$ and prediabetics $(2.18 \pm 0.28)$ (20), keeping $\alpha=0.05$ and power of 0.80 , a sample size of 48 participants was calculated.

After initial screening and confirmation of prediabetes (HbAlc between 5.7 and $6.4 \%$ and FBS between 100 and $125 \mathrm{mg} / \mathrm{dl}$ ), the participant demographics and body plethysmography (MiFit, Xiaomi, China) were determined, and written informed consent was obtained. Males were younger $(p=0.021)$, taller $(p<0.01)$, heavier $(p=0.06)$ and had more lean mass $(\mathrm{p}=0.03)$. In addition, $5 \mathrm{ml}$ blood was taken aseptically to determine the IL- 6 and TNF- $\alpha$ levels. The optimization of the exercise to define the exact speed at required intensity ( $55 \%$ to $65 \%$ of PMHR) was carried out on the second visit after screening the participants. This was performed using a treadmill attached to a breath-by-breath analyzer (Cosmed-Srl, Italy). This machine performs an accurate measurement of exercise-induced metabolism and calculates the required speed to elicit the desired intensity of exercise. The quantification of exercise was carried out by using pedometers (Mi-5 bands, Xiaomi, China), which counted the number of steps taken by each individual during the whole exercise session. After the optimization and quantification of exercise, verification of the exercise session was again performed on the following day in what was considered the first interventional trial. It was comprised of a 45 -minute session ( 5 minutes of warm up, 30 minutes of exercise at $55 \%$ to $65 \%$ of PMHR, and 10 minutes of cooling down). The participants were then asked to continue the same exercise protocol at home, 5 days per week for 3 months. They were supervised through pedometers, records of which were retrieved weekly after synchronizing the pedometer with software. Mean steps taken by females were more than males (4517 \pm 134 vs. $4125 \pm 121, \mathrm{p}=0.023)$; however, male participants performed more sessions (62 \pm 1 vs. $58 \pm 1, \mathrm{p}=0.01)$ during the entire exercise intervention, which lead to no significant difference between the total steps taken during the whole intervention ( $\mathrm{p}=$ 0.34). Measurements for anthropometric, diabetic, and inflammatory parameters were again determined at the post-interventional stage. SPSS version 20 was used for data analysis. The distribution of the data was assessed by the Kolmogorov-Smirnov and Shapiro-Wilk tests and found to be normal. Independent sample T statistics for mean difference between the groups (males vs. females) and paired sample statistics across the same group (pre vs. post) were used. 


\section{RESULTS}

A total of one hundred and twenty-six participants of both genders were screened, and out of them forty-eight individuals (36 males and 12 females) with pre-laid criteria were recruited into the study. The main reasons for fewer females in the study is the cultural norm of lesser involvement of females in physical activity programs.

The study yielded significant improvement in anthropometric (body mass and $\mathrm{BMI}$ ) and diabetic parameters (FBS and $\mathrm{HbAlc}$ ), and inflammatory markers (IL-6 and $\mathrm{TNF}-\alpha$ ), pointing towards a very strong role of moderate intensity exercise as an alternative to therapeutics and one of the strongest preventive measures against the development of diabetes.

\section{Pre-interventional stage}

The characteristics of all individuals are given in Table 1, subdivided by gender for comparing their anthropometric and biochemical parameters. These observations were made at the pre-test stage. A significant difference was observed for age $(p=0.021)$, height $(p<0.01)$, and body mass $(p=0.06)$. Females were less muscular $(p=0.03)$ and exhibited more fat mass $(\mathrm{p}=0.04)$. Exercise parameters indicate that at the same intensity males ran at higher speed $(p=0.02)$ and covered more distance $(p=0.01)$ at lower heart rate $(\mathrm{p}=0.001)$ during the exercise session, which shows better respiratory fitness in males, as determined by basal oxygen consumption difference $\mathrm{BVO}_{2}(\mathrm{p}$ $=0.02)$. Similarly, a trend towards significance was observed for BMI $(p=0.06)$ and FBS $(\mathrm{p}=0.067)$. At pre-stage levels, HbA1C, IL6, and TNF $\alpha$ did not show any male to female difference $(p=0.34,0.8 \& 0.9$, respectively).

\section{Inferential statistics}

Further analyses were carried out to assess the effect of a 12-week-long exercise protocol on body composition, substrate metabolism, and inflammatory profile of males and females. This was carried out through a paired sample test and described below:

\section{Body composition, cardiorespiratory fitness, diabetic and inflammatory profile}

The analyses revealed a significant reduction in BMI and body mass for both groups. A decrease, although not significant, was observed in body fat percentages of both.

The parameters for cardiorespiratory fitness and energy expenditure including basal heart rate $(\mathrm{BHR})$, heart rate during exercise (HR), basal oxygen consumption $\left(\mathrm{BVO}_{2}\right)$, oxygen consumption during exercise $\left(\mathrm{VO}_{2}\right)$, and energy expenditure (EE) were determined for both groups. Though the changes in the two groups at pre and post levels 
Table 1. Characteristics of the participants compared through an independent sample t-test

\begin{tabular}{|l|c|c|c|c|}
\hline & Total & Male & Female & P-Value \\
\hline Size (n) & 48 & 36 & 12 & \\
\hline Age (Years) & $30.7 \pm 7.80$ & $30.5 \pm 3.02$ & $31.17 \pm 3.7$ & $\mathbf{0 . 0 2 1}$ \\
\hline Height (m) & $1.63 \pm 0.09$ & $1.65 \pm 0.05$ & $1.59 \pm 0.3$ & $<\mathbf{0 . 0 1}$ \\
\hline Body mass (kg) & $75.04 \pm 8.24$ & $79.81 \pm 6.7$ & $66.8 \pm 5.07$ & $\mathbf{0 . 0 6}$ \\
\hline BMI (kg/m2) & $26.71 \pm 2.07$ & $27.07 \pm 1.35$ & $25.61 \pm 0.96$ & $\mathbf{0 . 0 6}$ \\
\hline Lean mass (kg) & $56.6 \pm 6.6$ & $65.03 \pm 3.2$ & $44.9 \pm 1.3$ & $\mathbf{0 . 0 3}$ \\
\hline Fat mass (kg) & $19.9 \pm 4.3$ & $14.27 \pm 7.2$ & $21.9 \pm 6.8$ & $\mathbf{0 . 0 4}$ \\
\hline Resting heart rate & $78 \pm 5$ & $76 \pm 4$ & $81 \pm 7$ & 0.30 \\
\hline Exercise HR & $114 \pm 5$ & $111 \pm 6$ & $120 \pm 4$ & $\mathbf{0 . 0 0 1}$ \\
\hline FBS (mg/dl) & $122 \pm 4$ & $123 \pm 2$ & $120 \pm 5$ & 0.47 \\
\hline HbA1C (\%) & $6.2 \pm 0.3$ & $6.08 \pm 0.22$ & $6.2 \pm 0.25$ & 0.34 \\
\hline Speed (km/hr) & $4.99 \pm 0.4$ & $5.3 \pm 0.3$ & $4.7 \pm 0.3$ & $\mathbf{0 . 0 2}$ \\
\hline Distance (km) & $2.5 \pm 0.8$ & $2.65 \pm 0.2$ & $2.35 \pm 0.2$ & $\mathbf{0 . 0 1}$ \\
\hline BVO (ml/kg/min) & $3.9 \pm 0.3$ & $4.0 \pm 0.2$ & $3.6 \pm 0.3$ & $\mathbf{0 . 0 2}$ \\
\hline VO (ml/kg/min) & $15.98 \pm 4.02$ & $17.02 \pm 4.3$ & $13.40 \pm 2.3$ & $\mathbf{0 . 0 0 4}$ \\
\hline Step count & $4211 \pm 195$ & $3902 \pm 201$ & $4432 \pm 174$ & 0.03 \\
\hline IL-6 pg/ml & $28 \pm 4$ & $26 \pm 4$ & $29 \pm 7$ & 0.9 \\
\hline TNF-a pg/ml & $24.5 \pm 5$ & $24 \pm 5$ & $23 \pm 6$ & 1.0 \\
\hline
\end{tabular}

The values presented include mean $\pm S D$, body mass index (BMI); fasting blood sugar (FBS), glycated haemoglobin $(\mathrm{HbAlC})$, basal oxygen consumption $\mathrm{BVO}_{2}(\mathrm{ml} / \mathrm{kg} / \mathrm{min})$, and oxygen consumption during exercise $\left(\mathrm{VO}_{2}\right)$.

were not significant, as shown in Table 2, they do show an improvement in cardiorespiratory fitness and metabolism in both groups.

A significant impact of exercise was found on the diabetic (FBS and HbA1C) and inflammatory profiles (IL6 and TNF- $\alpha$ ) for both males and females, as shown in Table 2 and Figure 1. 
Table 2. Body composition data for males and females at pre-and post-interventional stages

\begin{tabular}{|c|c|c|c|c|}
\hline \multicolumn{2}{|c|}{ Male $n=36$} & Pre & Post & P-Value \\
\hline \multirow{3}{*}{ Body composition } & BMI & $27.07 \pm 1.35$ & $26.6 \pm 1.35$ & $<0.001$ \\
\hline & Body mass $(\mathrm{kg})$ & $79.81 \pm 6.7$ & $78.03 \pm 6.8$ & $<0.001$ \\
\hline & Fat $\%$ & $17.99 \pm 2.1$ & $16.34 \pm 3.2$ & 0.23 \\
\hline \multirow{5}{*}{$\begin{array}{l}\text { Cardiorespiratory } \\
\text { fitness }\end{array}$} & Basal heart rate (BHR) & $77 \pm 6$ & $75 \pm 5$ & 0.6 \\
\hline & $\begin{array}{l}\text { Hear rate during exercise } \\
\text { (HR) }\end{array}$ & $111 \pm 6$ & $109 \pm 6$ & 0.4 \\
\hline & $\begin{array}{l}\text { Basal oxygen consumption } \\
\left(\mathrm{BVO}_{2}\right)\end{array}$ & $4.0 \pm 0.2$ & $3.8 \pm 0.4$ & 0.09 \\
\hline & $\begin{array}{l}\text { Oxygen consumption during } \\
\text { exercise }\left(\mathrm{VO}_{2}\right)\end{array}$ & $17.02 \pm 4.3$ & $16.02 \pm 3.9$ & 0.054 \\
\hline & Energy expenditure & $5.9 \pm 1.9$ & $5.2 \pm 0.8$ & 0.08 \\
\hline \multirow{2}{*}{ Diabetic profile } & FBS & $123 \pm 2$ & $114 \pm 2$ & 0.02 \\
\hline & $\mathrm{HbA1C}$ & $6.08 \pm 0.22$ & $5.78 \pm 0.27$ & 0.001 \\
\hline \multirow{2}{*}{$\begin{array}{l}\text { Inflammatory } \\
\text { profile }\end{array}$} & IL6 & $26 \pm 4$ & $20 \pm 6$ & .017 \\
\hline & TNF- $\alpha$ & $24 \pm 5$ & $18 \pm 6$ & .018 \\
\hline \multicolumn{5}{|c|}{ Female $n=12$} \\
\hline \multirow{3}{*}{ Body composition } & BMI & $25.61 \pm 0.96$ & $\begin{array}{c}25.34 \pm \\
0.73\end{array}$ & $<0.001$ \\
\hline & Body mass (kg) & $66.8 \pm 5.87$ & $\begin{array}{c}66.08 \pm \\
5.07\end{array}$ & $<0.001$ \\
\hline & Fat $\%$ & $32.87 \pm 3.4$ & $29.56 \pm 4.3$ & 0.64 \\
\hline \multirow{5}{*}{$\begin{array}{l}\text { Cardiorespiratory } \\
\text { fitness }\end{array}$} & Basal heart rate (BHR) & $85 \pm 3$ & $80 \pm 4$ & 0.3 \\
\hline & $\begin{array}{l}\text { Hear rate during exercise } \\
\text { (HR) }\end{array}$ & $120 \pm 4$ & $116 \pm 4$ & 0.23 \\
\hline & $\begin{array}{l}\text { Basal oxygen consump-tion } \\
\left(\mathrm{BVO}_{2}\right)\end{array}$ & $3.6 \pm 0.3$ & $3.5 \pm 0.3$ & 0.15 \\
\hline & $\begin{array}{l}\text { Oxygen consumption during } \\
\text { exercise }\left(\mathrm{VO}_{2}\right)\end{array}$ & $13.40 \pm 2.3$ & $13.21 \pm 3.3$ & 0.6 \\
\hline & Energy expenditure & $4.7 \pm 0.5$ & $4.4 \pm 0.7$ & 0.34 \\
\hline \multirow{2}{*}{ Diabetic profile } & FBS & $120 \pm 5$ & $95 \pm 12$ & .018 \\
\hline & $\mathrm{HbA1C}$ & $6.2 \pm 0.25$ & $5.87 \pm 0.31$ & .001 \\
\hline \multirow{2}{*}{$\begin{array}{l}\text { Inflammatory } \\
\text { profile }\end{array}$} & IL6 & $29 \pm 7$ & $18 \pm 6$ & .048 \\
\hline & TNF- $\alpha$ & $23 \pm 6$ & $16 \pm 5$ & .05 \\
\hline
\end{tabular}

BMI: Body mass index, FBS: Fasting blood sugar, HbA1C: Glycated haemoglobin, IL6: Interleukin-6, TNF- $\alpha$ : Tumor necrosis factor alpha 


\section{A Pre and Post FBS for Males and Females}

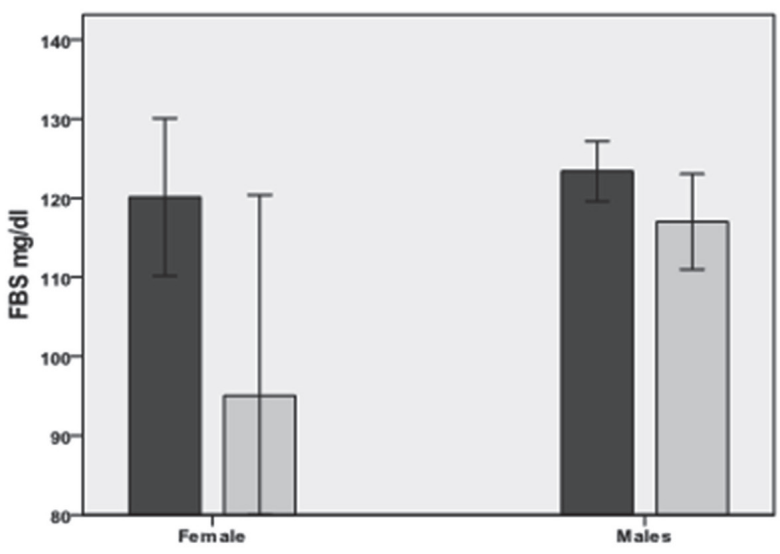

DFB_pre

口FBS-post

B

Pre and Post HbA1C for Males and Females

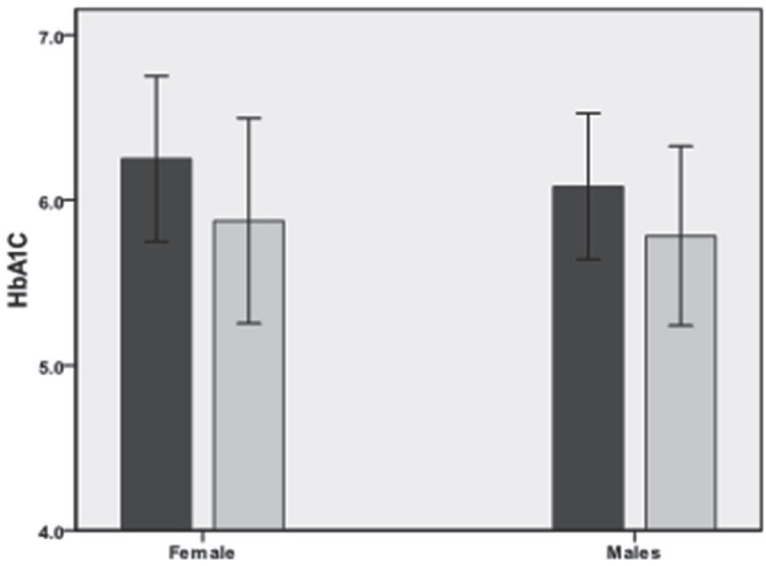

DhA1c_Pre

DHA1C_post

Figure 1a: Diabetic and inflammatory profiles of male and female participants at preand post-interventional stages: A) FBS,

B) $\mathrm{HbAlC}$ 
C

Pre and Post IL6 for Males and Females

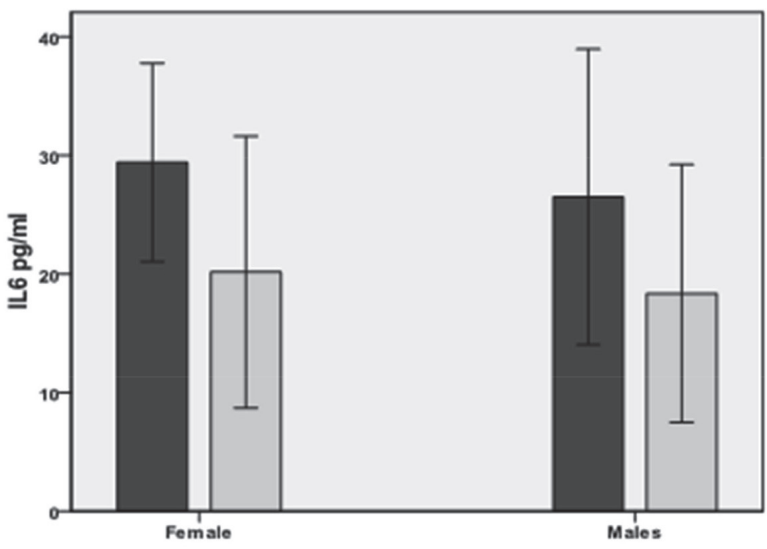

QR_pre

I6-post

D

Pre and Post TNF for Males and Females

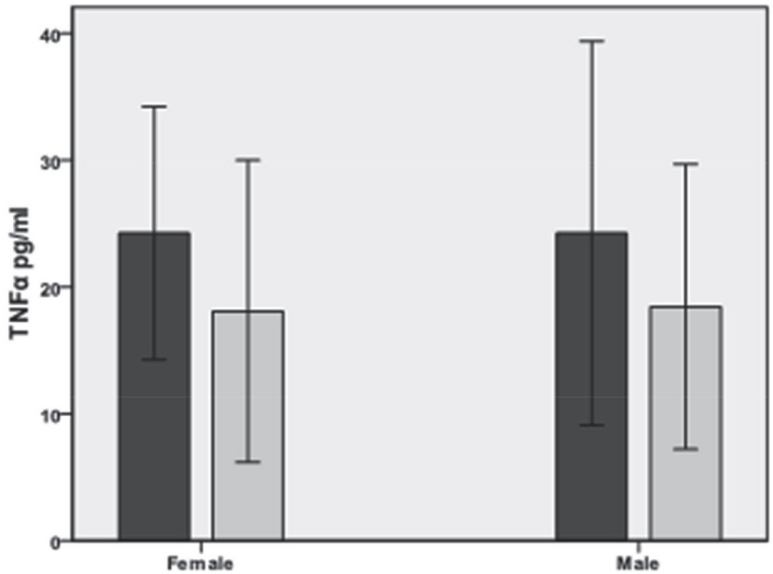

DTNF_pre

TNF-Post

Figure 1b: Diabetic and inflammatory profiles of male and female participants at preand post-interventional stages:

C) $I L-6$

D) $T N F-\alpha$ 


\section{DISCUSSION}

Pathologies related to impaired glucose tolerance (IGT) and impaired fasting glucose (IFG) are on the rise, leading to prediabetes and type II diabetes mellitus (Hordern et al., 2012). Prevalence of prediabetes is increasing with a projected load of more than 470 million people by the year 2030 across the globe (Tabák, Herder, Rathmann, Brunner, \& Kivimäki, 2012). The beneficial effects of exercise on prediabetes are already established and widely reported; therefore, a minimal recommendation of quantitative and qualitative physical activity has been suggested by WHO to counter prediabetes and prevent development of full-blown diabetes. However, the exact mechanisms of beneficial effects are poorly known. To date, the pharmaceutical approaches for the prevention of prediabetes have not been evaluated. Therefore, the desirable approaches for the prevention of prediabetes are lifestyle modification, exercise intervention, body mass reduction, and different physical activities (Grundy, 2012).

As diabetes is associated with disturbance in the inflammatory status of the body and prediabetes precedes diabetes, it is more likely that the changes in inflammatory status start before the onset of full-blown diabetes. Therefore, this study was designed to investigate effects of incorporating enhanced physical activities of a more structured and rigorous nature than ordinary daily routines. In more specific terms, the effects of exercise at intensity between 55\% and $65 \%$ of the PMHR was used as an intervention for change in inflammatory cytokines (IL- 6 and TNF- $\alpha$ ) in prediabetic males and females, with the aim that programmed exercise might influence the IL- 6 and TNF- $\alpha$. Moreover, it was also aimed at determining whether gender and variations in physical characteristic might be differently influenced.

From the findings, it is alarming to mention that out of 126 participants screened for the study based on their phenotypic appearance (age more than 25 years, overweight with central obesity, inactive and sedentary life style), 48 were found to be prediabetic which makes around $38 \%$ of the screened population. It is arguable that the majority of the selected participants were based on some observer bias, for example approaching those participant for screening which looked overweight in appearance. However, it still points towards a massive disease burden in the local community.

The recruited younger prediabetic population had elevated concentrations of TNF- $\alpha$ and IL-6 and at the baseline as shown in Table 1. These findings are similar to Andonian et al., (2018), who reported an association of the serum IL-6 levels with the body composition, which was reported to be greater in prediabetics (Andonian et al., 2018).

In addition, this study also reported a high concentration of IL-6 in males and a low concentration of TNF- $\alpha$ in female participants pointing towards gender based differences. Though these differences were not significant, similar cytokine profiles in the prediabetic population with gender disparity have been reported previously (Lucas et al., 2013).

Moreover, serum TNF- $\alpha$ levels decreased significantly after the advised exercise protocol, as shown in Table 2 and Figure 1. These findings are in line with the findings of Starkie, Ostrowski, Jauffred, Febbraio, \& Pedersen (2003), who suggested that inhibition of TNF- $\alpha$ production in healthy human subjects is affected by physical exercise 
of different intensities (Starkie et al., 2003). Similarly, Keller, Keller, Giralt, Hidalgo, \& Pederson, (2004) proposed that high TNF- $\alpha$ inhibits insulin receptor, signaling that leads to insulin resistance. They examined the effects of 60 minutes of exercise on overexpressed TNF- $\alpha$ in mice and suggested that the expression decreases after a single bout of exercise (Keller et al., 2004; Gleeson, 2000).

The current study showed that a significant decrease in exercise induced IL-6 production. These findings are in line with the findings of Pederson \& Fischer, (2007), who proposed that the TNF- $\alpha$ production is increased in low-grade inflammatory conditions like T2DM and that raised IL-6 inhibits the TNF- $\alpha$ induced insulin resistance (Pederson \& Fischer, 2007). Olson, Dengel, Leon, \& Schimtz, (2007) conducted a study including 28 female participants (with the BMI $\geq 25 \mathrm{~kg} / \mathrm{m}^{2}$ ) and studied different serum markers before and after 1 year of resistance training. They reported that moderate intensity resistance training results in significant improvement of the inflammatory markers Creactive protein (CRP) and interleukin-6 (IL-6) (Olson et al., 2007). The increase in some inflammatory markers, such as IL-6, also stimulates fat oxidation and lipolysis. Exercise provides one of the best tools to expose the body to challenges through increased production of some of the inflammatory markers acutely and then conditioning the body to clear it (Peterson \& Pedersen, 2005).

In addition, an improvement in the body composition (body mass, BMI) ( $p<0.01$ for all) in the prediabetics was observed. From the findings, it is obvious that all participants were overweight at the start due to selection bias. However, similar findings related to greater muscle myostatin, cytokines, and the body composition have been reported elsewhere (Andonian et al., 2018). The reductions in body mass parameters are generally perceived as one of the good indicators of any intervention and that was the reason why no drop-out was observed in the study population.

Similarly, this study reported a significant reduction in HbA1c levels $(6.2 \pm 0.25$ to $5.87 \pm 0.31 \mathrm{p}<0.001$ ) after exercise training. Bweir et al. (2009) recruited 20 inactive diabetic patients and assigned them resistance exercise for 10 weeks, reporting a significant reduction in HbA1c levels (Bweir et al., 2009). In another study, Najafipour et al. conducted a training program on diabetic patients including three 90-minute sessions of exercise per week, at 50\%-80\% $\mathrm{VO}_{2}$ max, and reported significant improvement in BMI, $\mathrm{HbA} 1 \mathrm{C}$, and $\mathrm{VO}_{2}$ max values $(\mathrm{p}<0.05$ for all) (Najafipour et al., 2017). $\mathrm{VO}_{2}$ max shows respiratory fitness, and the findings of this study support the already existing literature. Though the findings of cardiorespiratory fitness in our cohort were not significant, all the parameters exhibited improvement, as shown in Table 2. It can be ascertained that exercise protocols designed at higher intensities may improve cardiorespiratory fitness significantly. Participants in our study were sedentary and involving them in high intensity intervention could have created health hazards.

It is necessary to note that although the 3-month exercise protocol months did not change the status of the individual from prediabetic to normal, a decrease in diabetic and inflammatory parameters were observed for males and females. Therefore, based on the findings of this study it can be assumed that incorporation of this protocol into a 
patient's lifestyle for longer duration (6 months) may change their prediabetic status to normal. This, however, warrants another study for longer duration.

The Physical Activity Guidelines issued by the United States Department of Health and Human Services suggest that patients with diabetes should engage in 2.5 hours of physical activity per week and if there are no contraindications they must be encouraged to perform resistance training 3 times per week. There are different studies suggesting that T2DM develops in individuals who are inactive (Earnest, 2008; Malin, 2012). Exercise training, along with lifestyle changes, has favorable effects on averting the onset of prediabetes. It is generally recommended that prediabetic patients should perform moderate intensity exercise for a minimum of 210 minutes per week (Hordern et al., 2012). Various exercise guidelines by different organizations have recommended that exercise be performed at different intensities based on maximal capacity and little is known regarding the optimal intensities of exercise (Earnest, 2008). The general perception is that incorporation of moderate intensity exercise may pose a great challenge to the investigator and the participants. However, it was not the case here and exercise was incorporated as an effective alternative to the life style of all the participants in the study with little motivation and counselling.

Systemic low-grade chronic inflammation is linked with T2DM, which can lead to the development of various complications. Exercise training can improve inflammation biomarkers and reduce the risk of such complications in these subjects (Hopps et al., 2011). Chronic inflammation-based health problems can be effectively prevented with regular exercise. Long-term regular exercise encourages the coping mechanisms in the body to counteract the acute production of inflammatory markers. In this fashion the body becomes more conditioned and effectively counteracts the raised inflammatory markers. It is worth mentioning that such physical activities are easy to incorporate with little motivation and dedication.

\section{CONCLUSION}

Significant reduction in inflammatory cytokines (IL-6 and TNF- $\alpha$ ) was observed after regular 45 -minute exercise at $55 \%$ to $65 \%$ of PMHR training performed for 3 months, which suggests possible preventive effects of exercise on chronic inflammation-based health problems such as diabetes. Exercise is a natural way to cope with low-grade anti-inflammatory conditions, has very few side effects and can easily be incorporated into the prediabetic patient's lifestyle (Pederson, 2017).

\section{Future directions}

The disease burden of prediabetes is enormous in our area and a strong awareness campaign about the prevention of prediabetes is required. Masses with diagnosed pre- 
diabetes or at risk should consider adopting an active life style and engaging in physical activities to prevent the development of full-blown type II diabetes.

\section{Limitations of the study}

The current study has some limitations. We did not recruit a control group of healthy patients to compare with our values. Moreover, we did not advise vigorous intensity exercise to the participants to look for the effects on IL-6 and TNF- $\alpha$. There were more male than female participants in the study; an equal number of participants in both groups could have yielded better results. In addition, no diet restrictions were imposed on the participants, which is a potential confounding variable in the quantification of the effect of exercise on body composition, and the diabetic/inflammatory profile.

\section{References}

Aamir, A. H., Ul-Haq, Z., Mahar, S. A., Qureshi, F. M., Ahmad, I., Jawa, A., ... Heald, A. H. (2019). Diabetes Prevalence Survey of Pakistan (DPS-PAK): prevalence of type 2 diabetes mellitus and prediabetes using $\mathrm{HbA1c}$ : a population-based survey from Pakistan. BMJ open, 9(2), e025300. http://dx.doi.org/10.1136/bmjopen-2018-025300.

Andonian, B. J., Bartlett, D. B., Huebner, J. L., Willis, L., Hoselton, A., Kraus, V. B., ... Huffman, K. M. (2018). Effect of high-intensity interval training on muscle remodeling in rheumatoid arthritis compared to prediabetes. Arthritis Research \& Therapy, 20(283), 1-9. https://doi.org/10.1186/s13075-018-1786-6.

Bweir, S., Al-Jarrah, M., Almalty, A.-M., Maayah, M., Smirnova, I. V., Novikova, L. \& Stehno-Bittel, L. (2009). Resistance exercise training lowers HbA1c more than aerobic training in adults with type 2 diabetes. Diabetology \& Metabolic Syndrome, 1(27). https://doi.org/10.1186/1758-5996-1-27.

Earnest, C. P. (2008). Exercise interval training: an improved stimulus for improving the physiology of pre-diabetes. Medical Hypotheses, 71(5), 752-761. https://doi. org/10.1016/j.mehy.2008.06.024.

Gleeson, M. (2000). Interleukins and exercise. The Journal of Physiology, 529(1), 1-1. https://doi.org/10.1111/j.1469-7793.2000.00001.x.

Golbidi, S., Badran, M. \& Laher, I. (2011). Antioxidant and anti-inflammatory effects of exercise in diabetic patients. Experimental Diabetes Research, 2012. https://doi. org/10.1155/2012/941868.

Grundy, S. M. (2012). Pre-diabetes, metabolic syndrome, and cardiovascular risk. Journal of the American College of Cardiology, 59(7), 635-643. https://doi.org/10.1016/j. jacc.2011.08.080.

Hopps, E., Canino, B. \& Caimi, G. (2011). Effects of exercise on inflammation markers in type 2 diabetic subjects. Acta Diabetologica, 48, 183-189. https://doi.org/10.1007/ s00592-011-0278-9.

Hordern, M. D., Dunstan, D. W., Prins, J. B., Baker, M. K., Singh, M. A. F. \& Coombes, J. S. (2012). Exercise prescription for patients with type 2 diabetes and pre-diabetes: a 
position statement from Exercise and Sport Science Australia. Journal of Science and Medicine in Sport, 15(1), 25-31. https://doi.org/10.1016/j.jsams.2011.04.005.

Keller, C., Keller, P., Giralt, M., Hidalgo, J. \& Pederson, B. K. (2004). Exercise normalises overexpression of TNF- $\alpha$ in knockout mice. Biochemical and Biophysical Research Communications, 321(1), 179-182. https://doi.org/10.1016/j.bbrc.2004.06.129.

Lucas, R., Parikh, S. J., Sridhar, S., Guo, D.-H., Bhagatwala, J., Dong, Y., ... Zhu, H. (2013). Cytokine profiling of young overweight and obese female African American adults with prediabetes. Cytokine, 64(1), 310-315. https://doi.org/10.1016/j. cyto.2013.05.025.

Malin, S. K., Gerber, R., Chipkin, S. R. \& Braun, B. (2012). Independent and combined effects of exercise training and metformin on insulin sensitivity in individuals with prediabetes. Diabetes Care, 35(1), 131-136. https://doi.org/10.2337/dc11-0925.

Najafipour, F., Mobasseri, M., Yavari, A., Nadrian, H., Aliasgarzadeh, A., Abbasi, N. M., ... Sadra, V. (2017). Effect of regular exercise training on changes in HbA1c, BMI and VO2max among patients with type 2 diabetes mellitus: an 8-year trial. BMJ Open Diabetes Research and Care, 5(1). https://doi.org/10.1136/bmjdrc-2017-000414.

Olson, T. P., Dengel, D., Leon, A. \& Schimtz, K. (2007). Changes in inflammatory biomarkers following one-year of moderate resistance training in overweight women. International Journal of Obesity, 31, 996-1003. https://doi.org/10.1038/sj.ijo.0803534.

Pederson, B. K. (2017). Anti-inflammatory effects of exercise: role in diabetes and cardiovascular disease. European Journal of Clinical Investigation, 47(8), 600-611. https://doi. org/10.1111/eci.12781.

Pederson, B. K. \& Fischer, C. P. (2007). Beneficial health effects of exercise-the role of IL-6 as a myokine. Trends in Pharmacological Sciences, 28(4), 152-156. https://doi. org/10.1016/j.tips.2007.02.002.

Peterson, A. M. W. \& Pedersen, B. K. (2005). The anti-inflammatory effect of exercise. Journal of Applied Physiology, 98(4), 1154-1162. https://doi.org/10.1152/japplphysiol.00164.2004.

Starkie, R., Ostrowski, S. R., Jauffred, S., Febbraio, M. \& Pedersen, B. K. (2003). Exercise and IL-6 infusion inhibit endotoxin-induced TNF- $\alpha$ production in humans. The FASEB Journal, 17(8), 1-10. https://doi.org/10.1096/fj.02-0670fje.

Straczkowski, M., Kowalska, I., Dzienis-Straczkowska, S., Stepien, A., Skibinska, E., Szelachowska, M. \& Kinalska, I. (2001). Changes in tumor necrosis factor-alpha system and insulin sensitivity during an exercise training program in obese women with normal and impaired glucose tolerance. European Journal of Endocrinology, 145(3), 273-280. https://doi.org/10.1530/eje.0.1450273.

Tabák, A. G., Herder, C., Rathmann, W., Brunner, E. J. \& Kivimakli, M. (2012). Prediabetes: a high-risk state for diabetes development. The Lancet, 379(9833), 2279-2290. https://doi.org/10.1016/S0140-6736(12)60283-9. 